Eur. J. Clin. Chem. Clin. Biochem.

Vol. 29, 1991, pp. 537-547

(C) 1991 Walter de Gruyter \& Co. Berlin - New York

\title{
Mechanized Toxicological Serum Tests in Screening Hospitalized Patients
}

\author{
By J. Hallbach and W. G. Guder \\ Institut für Klinische Chemie, Städtisches Krankenhaus München-Bogenhausen
}

(Received December 21, 1990/May 17, 1991)

Summary: A spectrum of quantitative and qualitative methods was adapted to the RA-1000/RA-XT selective analyser for the purpose of excluding or detecting common types of intoxication in the emergency laboratory of our primary care community hospital. Ethanol and salicylates (measured photometrically) and acetaminophen (measured immunologically by EMIT tox) were quantitatively analysed in serum. Immunological group tests (EMIT tox) for barbiturates, benzodiazepines, tricyclic antidepressants and related compounds were used for qualitative analysis. Well established clinical chemical methods (aspartarte aminotransferase, alanine aminotransferase, creatine kinase, pseudocholinesterase, glucose and lactate) were applied to the serum samples using the same selective analyser. Within and between run precision, accuracy, recovery and detection ranges (linearity) fulfilled the recommendations of forefield toxicological analysis for all methods.

Ethanol (g/l), measured photometrically with the RA-1000 analyser, agreed with the reference method (headspace gas-chromatography) with a correlation coefficient $>0.99(\mathrm{y}=0.06+0.98 \mathrm{x})$. Acetaminophen and salicylates showed correlation coefficients $>0.94$ and $>0.99$, when compared with manual colorimetric procedures (acetaminophen $(\mathrm{mg} / \mathrm{l}): \mathrm{y}=-3.22+0.896 \mathrm{x}$; salicylates $(\mathrm{mg} / \mathrm{l}): \mathrm{y}=-2.1+1 \mathrm{x})$. Qualitative group tests for barbiturates, benzodiazepines and tricyclic antidepressants measured with the RA-1000 analyser were in good agreement with the EMIT single test procedure.

The ranges of the quantitative methods allowed quantification of analytes from therapeutic (non-toxic) to very high levels in undiluted samples (ethanol 0.05 up to $4 \mathrm{~g} / \mathrm{l}$; salicylates 32 up to $1200 \mathrm{mg} / \mathrm{l}$ and acetaminophen 1.9 up to $200 \mathrm{mg} / \mathrm{l})$. The low detection limits of the qualitative tests allowed the recognition of compounds in plasma that were present in low concentrations and/or displayed only minor reactivity with the antibodies provided by the EMIT tox test kits.

As a consequence, decision limits for all three group tests in serum were lowered to near the detection limit:

Bạrbiturates:

Benzodiazepines:

Tricyclic antidepressants:
$0.5 \mathrm{mg} / \mathrm{l}$ (calibrated with secobarbital)

$0.05 \mathrm{mg} / 1$ (calibrated with nordiazepam)

$0.07 \mathrm{mg} / 1$ (calibrated with nortriptyline)

For quantitative tests the lower limits of quantification were:

$\begin{array}{ll}\text { Acetaminophen: } & 10 \mathrm{mg} / \mathrm{l} ; \\ \text { Salicylates: } & 50 \mathrm{mg} / \mathrm{l} ; \\ \text { Ethanol: } & 0.15 \mathrm{~g} / 1 .\end{array}$

The working reagents were stable for at least 14 days at $4-8^{\circ} \mathrm{C}$. Calibration curves were stable over the expiration period of reconstituted original reagents (6-12 weeks), also when working reagents were prepared in aliquots from stored reconstituted reagents. 
Application of the newly adapted programme to serum samples of nearly two hundred patients showed it to be suitable for screening patients in which intoxication is suspected or needs to be excluded.

\section{Introduction}

Despite the importance of checking for acute intoxication and chronic drug abuse in newly hospitalized patients, toxicological analysis is not practised as widely in German hospitals (1) as recommended by an expert group (2). This is probably due to the effort required for the application of most of the available procedures.

Intoxications are usually first detected by qualitative tests (3) based either on direct examination of urine or of acidic or basic extracts. Moreover, drug-abundance control programmes are commonly based on the analysis of urine (4), because most substances can be detected for a longer period in urine than in serum. However, the severity of an intoxication can only be derived from plasma values. Apparently, the procedures based on urine analysis (5) do not adequately meet the requirements for detection or exclusion of acute intoxication in the emergency laboratory. Serum or plasma is the primary sample material of newly hospitalized patients, and its drug content mirrors the actual state of intoxication better than that of urine. An analytical programme for serum or plasma therefore seemed more appropriate.

Many substances appear in only low levels in pläsma and urine, following the administration of toxicologically relevant doses. Furthermore, various immunological detection systems used for group-specific measurements differ widely in their sensitivity to different substances within the one group. To overcome these problems, extraction, hydrolysis of conjugates and reduction of decision limits have been suggested as appropriate solutions $(6-9)$. For the present needs of a toxicological emergency programme only those procedures which need little additional effort seemed appropriate.

Our purpose was therefore to develop an automated toxicological screening programme for serum by combining quantitative and qualitative measurements, and to considerably reduce the operational time and the cost by adapting the methodology to a selective analyser.

The aim was to exclude, differentiate and quantify various frequent forms of intoxication. The present methodology can be adapted to a great number of other mechanised analysers. Parts of this work have been presented in a preliminary form $(10-12)$.

\section{Materials and Methods}

Plasma or serum samples

Samples were drawn as soon as possible after admission of the patient to the hospital. Blood was collected in $4 \mathrm{ml}$ serum or plasma separator tubes (Vacutainer ${ }^{\oplus}$, Becton Dickinson, Meylan Cedex, France) with lithium heparinate as anticoagulant.

\section{Analytical procedures}

Table 1 summarizes the parameters for adaptation of qualitative procedures, table 2 of quantitative procedures to the RA-1000/ RA-XT selective analyser (Bayer Diagnostik-Technicon, München, Germany). A software version including immunoassay test capabilities is recommended.

\section{Barbiturates}

Barbiturates were measured by enzyme multiplied immunoassay (EMIT), using a test kit (EMIT tox barbiturates) purchased from Syva, Darmstadt, Germany. Stock reagents were prepared as prescribed by the manufacturer. For preparation of working solutions, reagent 1 (group-specific antibodies, substrates) and reagent 2 (enzyme-linked secobarbital as tracer) were diluted 10-fold with the buffer solution. Using the RA-1000 analyser, plasma $(3.5 \mu \mathrm{l})$ was mixed with $175 \mu \mathrm{l}$ working solution 1 , and $30 \mathrm{~s}$ later $175 \mu \mathrm{l}$ working solution 2 was added. After an additional $30 \mathrm{~s}$ the kinetics were recorded in a period of $30 \mathrm{~s}$. Barbiturate calibrators A-C (Abbott Diagnostics, Wiesbaden, Germany) were used. A calibration curve was constructed using these standards or mixtures thereof containing concentrations of $0,0.5,2.0$ and $3.5 \mathrm{mg} / 1$ secobarbital respectively.

This method was compared with the EMIT single test (Syva, Darmstadt, Germany), using the photometer from the same manufacturer.

\section{Benzodiazepines}

The procedure for benzodiazepines was analogous to the method for barbiturates using a test kit (EMIT tox benzodiazepines) from Syva, Darmstadt, Germany.

Benzodiazepine calibrators $A=F$ (Abbott Diagnostics, Wiesbaden, Germany) were used as standards. A calibration curve was constructed using concentrations of $0,0.05,0.1,0.2$ and $0.4 \mathrm{mg} / \mathrm{l}$ nordiazepam.

This method was compared with the EMIT single test (Syva, Darmstadt, Germany).

\section{Tricyclic antidepressants}

Tricyclic antidepressants and related compounds were also measured by adaptation of an EMIT procedure (EMIT tox TCA, Syva, Darmstadt, Germany) to the RA-1000 analyser.

Tricyclic Antidepressant calibrators A-D (Abbott Diagnostics, Wiesbaden, Germany) were used as standards. A calibration curve was constructed using concentrations of $0,0.07,0.15$ and $0.3 \mathrm{mg} / 1$ nortriptyline.

This method was compared with the EMIT single test (Syva, - Darmstadt, Germany). 
Tab. 1. Instrumental settings for qualitative EMIT tests in plasma on the RA-1000 analyser.

\begin{tabular}{lllc}
\hline $\begin{array}{l}\text { Parameter } \\
\text { (group reaction) }\end{array}$ & Barbiturates & Benzodiazepines & $\begin{array}{l}\text { Tricyclic } \\
\text { antidepressants }\end{array}$ \\
\hline Reaction type* & 1 & 1 & 1 \\
Sample volume & $7 \%(3.5 \mu \mathrm{l})$ & $7 \%(3.5 \mu \mathrm{l})$ & $7 \%(3.5 \mu \mathrm{l})$ \\
Wavelength & $1(340 \mathrm{~nm})$ & $1(340 \mathrm{~nm})$ & $1(340 \mathrm{~nm})$ \\
Preincubation time** & $60 \mathrm{~s}$ & $60 \mathrm{~s}$ & $60 \mathrm{~s}$ \\
Incubation time & $30 \mathrm{~s}$ & $30 \mathrm{~s}$ & $30 \mathrm{~s}$ \\
Reading time & $30 \mathrm{~s}$ & $30 \mathrm{~s}$ & $30 \mathrm{~s}$ \\
Reagent 1 volume & $35 \%(175 \mu \mathrm{l})$ & $35 \%(175 \mu \mathrm{l})$ & $35 \%(175 \mu \mathrm{l})$ \\
Reagent 2 volume & $35 \%(175 \mu \mathrm{l})$ & $35 \%(175 \mu \mathrm{l})$ & $35 \%(175 \mu \mathrm{l})$ \\
Unit & $7(\mathrm{mg} / \mathrm{l})$ & $7(\mathrm{mg} / \mathrm{l})$ & $7(\mathrm{mg} / \mathrm{l})$ \\
Detection limit*** & 5.0 & 0.6 & 0.5 \\
Normal range**** & 0.5 & 0.05 & 0.07 \\
1.0. limit & 0.05 & 0.05 & 0.05 \\
Immunoassay type & 0 & 0 & 0 \\
Calibrator 1 & 0 & 0 & 0 \\
Calibrator 2 & 0.5 & 0.05 & 0.07 \\
Calibrator 3 & 2.0 & 0.1 & 0.15 \\
Calibrator 4 & 3.5 & 0.2 & 0.3 \\
Calibrator 5 & - & 0.4 & - \\
LIM 1 to LIM 4 (5) & 10 & 10 & 10 \\
SLM 1 to SLM 4 (5) & 99 & 99 & 99 \\
10/50/90 PAW & 99.00 & 99.00 & 99.00 \\
\%10/\%50/\%100 PAW & 99 & 99 & 99 \\
SFQ LIMIT & 10 & 10 & 10 \\
\hline
\end{tabular}

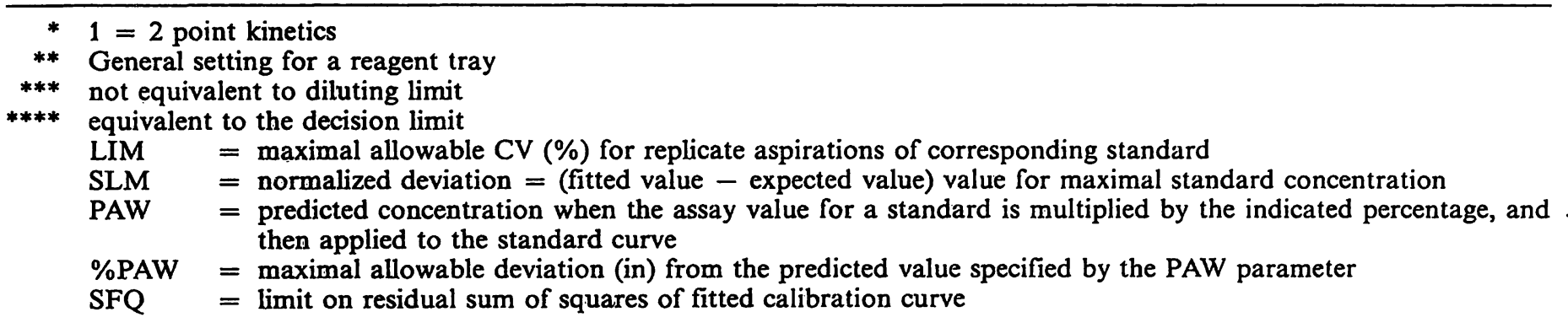

Tab. 2. Instrumental settings for quantitative determination of the plasma analytes on the RA-1000 analyser.

\begin{tabular}{|c|c|c|c|}
\hline Parameter & Acetaminophen & Salicylates & Ethanol \\
\hline Reaction type* & 1 & 2 & 2 \\
\hline Sample volume & $7 \%(3.5 \mu l)$ & $60 \%(30 \mu \mathrm{l})$ & $4 \%(2 \mu \mathrm{l})$ \\
\hline Wavelength & $1(340 \mathrm{~nm})$ & $5(550 \mathrm{~nm})$ & $1(340 \mathrm{~nm})$ \\
\hline Preincubation time ${ }^{* *}$ & $60 \mathrm{~s}$ & $60 \mathrm{~s}$ & - \\
\hline Incubation time & $30 \mathrm{~s}$ & $300 \mathrm{~s}$ & $300 \mathrm{~s}$ \\
\hline Reading time & $30 \mathrm{~s}$ & - & - \\
\hline Reagent 1 volume & $35 \%(175 \mu \mathrm{l})$ & $67 \%(335 \mu l)$ & $75 \%(375 \mu l)$ \\
\hline Reagent 2 volume & $35 \%(175 \mu \mathrm{l})$ & $7 \%(35 \mu \mathrm{l})$ & - \\
\hline Unit & $7(\mathrm{mg} / \mathrm{l})$ & $7(\mathrm{mg} / \mathrm{l})$ & $(g / l)$ \\
\hline Detection limit & $200 \mathrm{mg} / \mathrm{l}$ & $1200 \mathrm{mg} / \mathrm{l}$ & $4 \mathrm{~g} / \mathrm{l}$ \\
\hline Cal. Factor & - & $\mathbf{x x x x}$ & 1.99 \\
\hline Normal range $+* * *$ & $10 \mathrm{mg} / 1$ & $50 \mathrm{mg} / \mathrm{l}$ & $0.15 \mathrm{~g} / 1$ \\
\hline Reagent blank & - & 0.0 & 0.0 \\
\hline 1.0. limit & 1.0 & - & - \\
\hline Endpoint lim. & - & 0.02 & 0.05 \\
\hline Immunoassay type & 0 & - & - \\
\hline Calibrator 1 & $0 \mathrm{mg} / 1$ & $250 \mathrm{mg} / 1$ & - \\
\hline Calibrator 2 & $10 \mathrm{mg} / 1$ & - & - \\
\hline Calibrator $\overline{3}$ & $25 \mathrm{mg} / 1$ & - & - \\
\hline Calibrator 4 & $50 \mathrm{mg} / 1$ & - & - \\
\hline Calibrator 5 & $100 \mathrm{mg} / 1$ & - & - \\
\hline Calibrator 6 & $200 \mathrm{mg} / \mathrm{l}$ & - & - \\
\hline LIM 1 to LIM 6 & 10 & - & - \\
\hline SLM 1 to SLM 6 & 99 & - & - \\
\hline $10 / 50 / 90$ PAW & 99.0 & - & - \\
\hline$\% 10 / \% 50 / \% 90$ PAW & 99 & - & - \\
\hline SFQ LIM & 10 & - & - \\
\hline
\end{tabular}

* $1=2$ point kinetics; 2 = endpoint 


\section{Acetaminophen}

The EMIT procedure (EMIT tox Acetaminophen, Syva, Darmstadt) was adapted to the RA-1000 analyser using working reagents preparcd as for the qualitative methods above.

For preparation of the standard curve, calibrators provided with the test kit werc used. The calibration curve was constructed using concentrations of $0,10,25,50,100$ and $200 \mathrm{mg} / 1$.

This method was compared with a manual colorimetric method after enzymatic hydrolysis (13) using a test kit purchased from Cambridge Life Sciences, London, UK.

\section{Salicylates}

A colorimetric procedure using a test kit from Sigma, Deisenhofen, Germany was adapted to the RA-1000 selective analyser. The blank reagent provided was used as working solution 1. Working solution 2 was prepared by mixing 7.6 parts blank reagent and one part colour reagent, and this mixture was stable at $4^{\circ} \mathrm{C}$ for at least 4 weeks. As can be seen from table $2,30 \mu \mathrm{l}$ plasma were mixed with $335 \mu \mathrm{l}$ working solution 1 and 60 seconds later $35 \mu \mathrm{l}$ working solution 2 was added. After $300 \mathrm{~s}$ the final reading at $550 \mathrm{~nm}$ was taken. A standard solution of $250 \mathrm{mg} / \mathrm{l}$ salicylate provided with the test kit was used for calibration. A sample blank using working reagent 1 alone was measured in parallel.

This method was compared with the manual method using the same test kit from Sigma.

\section{Ethanol}

The alcohol dehydrogenase (EC 1.1.1.1) method was adapted to the RA-1000 analyser. Reagents, i. e. NAD/ADH-suspension and glycine buffer containing a non-specified aldehyde captor, were purchased from Sigma (Deisenhofen, Germany). Working reagent was prepared as prescribed by the manufacturer, and it was stable for at least 48 hours below $15^{\circ} \mathrm{C}$. Plasma $(2 \mu \mathrm{l})$ was mixed with $375 \mu \mathrm{l}$ reagent and a final reading at $340 \mathrm{~nm}$ was taken $300 \mathrm{~s}$ thereafter. The concentration of ethanol was calculated, using the molar absorbance coefficient of NADH at $340 \mathrm{~nm}$ and the factor of 1.992 . The method was compared with the headspace gas chromatography procedure according to l.c. (14).

\section{Control materials}

The intra-assay and inter-assay precision for the analysis of all analytes except ethanol were determined with a mixture of Lyphochek TDM Level-1 (Biorad, Munich, Germany) and Control Benzodiazepine Serum Level-M (Abbott Diagnostics, Wiesbaden, Germany). The mixture was prepared by dissolving the Lyphochek control in the fluid benzodiazepine control $(2.5$ $\mathrm{ml}$ ), followed by the addition of $2.5 \mathrm{ml}$ distilled water. Samples from patients were also used for assessing precision data.

To determine the precision and accuracy of the ethanol method, different charges of Fluinorm Ethanol R Level I and II (Behringwerke, Marburg, Germany) were used. The accuracy of the acetaminophen assay was measured with Lyphochek TDM Level-3 (Biorad, Munich, Germany) and Control Acetaminophen (Syva, Darmstadt, Germany). Lyphochek TDM Level 2/3 were used to determine the accuracy of the salicylate assay. The calibration curves of the qualitative determinations were checked with Barbiturates Control L, Benzodiazepines Control $\mathrm{L}$ and Tricyclic Antidepressants Control M (all from Abbott, Wiesbaden, Germany), and additionally with EMIT st Serum Calibrator and EMIT st tricyclic antidepressants Calibrator (Syva, Darmstadt, Germany).

\section{Statistical evaluation}

Linear regression analysis was performed using the least square analysis method (15). In addition, the general regression procedure described by Bablok et al. was applied using the computer program provided by these authors (16).

The analytical sensitivity of the qualitative immunological screening tests was evaluated by the method introduced by Kutter (17). The decision limit of the qualitative tests was extended as described in 1.c. $(8,18,19)$.

Test results for qualitative methods were compared by testing for discordancies with the four-field-technique.

\section{Results}

\section{Adaptation of methods}

The aim of the present study was to take a combination of quantitative and qualitative methods for recognizing acute intoxication with frequently abused drugs, and to adapt them to an analyser, which is used routinely in the clinical chemistry emergency laboratory. Using the settings summarized in table 1 and table 2 this was realised on the RA $\div 1000 / \mathrm{RAXT}$ analyser. The total programme can be performed in 10 minutes using heparin plasma or serum samples.

In addition, bidirectional communication with a laboratory computer system reduces the work of the technician in delivering sample and control into the sample cups and in starting the analyser.

\section{Detection and linearity limits}

The detection limit of the assays (mean $+3 \mathrm{SD}$ ) was determined by measuring 30 different drug-free samples (tab. 3). The immunological assays showed a linear response up to the highest calibrator level, and this was confirmed by measuring different dilutions of samples exhibiting high drug concentrations.

Test results including qualitative determination exceeding the calibration range should be confirmed by analysing a diluted sample. It is recommended that dilution be performed with a drug-free sample; most control materials used in clinical chemistry. are suitable for this purpose. As shown in table 3 the linearity limits for ethanol, acetaminophen and salicylates were $4.0 \mathrm{~g} / \mathrm{l}, 200 \mathrm{mg} / \mathrm{l}$ and $1200 \mathrm{mg} / \mathrm{l}$, respectively.

\section{Analytical precision and accuracy}

The intra-assay and inter-assay precisions are summarized in table 4.

Intra- and inter-assay precision for ethanol was in the usual range for alcohol dehiydrogenase methods 
Tab. 3. Detection and linearity limits of the qualitative and quantitative methods used.

\begin{tabular}{lccc}
\hline Analyte & Unit & $\begin{array}{l}\text { Detection } \\
\text { limit }\end{array}$ & $\begin{array}{l}\text { Linearity } \\
\text { limit }\end{array}$ \\
\hline Barbiturates & $\mathrm{mg} / \mathrm{l}$ & 0.04 & 3.5 \\
Benzodiazepines & $\mathrm{mg} / \mathrm{l}$ & 0.04 & 0.4 \\
Tricyclic antidepressants & $\mathrm{mg} / \mathrm{l}$ & $(0)$ & 0.3 \\
Acetaminophen & $\mathrm{mg} / \mathrm{l}$ & 1.9 & 200 \\
Salicylates & $\mathrm{mg} / \mathrm{l}$ & 32 & 1200 \\
Ethanol & $\mathrm{g} / \mathrm{l}$ & 0.04 & 4.0 \\
\hline
\end{tabular}

$\left.(\mathrm{CV} \%<8 \%)^{1}\right)$. Variations for acetaminophen and salicylates were in the range usually accepted for drug monitoring, i.e. less than $10 \%$.

Although barbiturates, benzodiazepines and tricyclic antidepressants are only determined qualitatively, pre-

1) permitted limit of deviation for low levels of ethanol (external quality control from the Deutsche Gesellschaft für Klinische Chemie, Bonn, Germany) cision data can be given, because primary results are quantitative and transformed into qualitative results by setting a decision limit.

A special feature of the EMIT principle is the sometimes higher precision with low rather than high analyte concentrations. Accuracies measured with control materials are summarized in table 5. Although the methods used for determination of the target values were not the same as the adapted methods, the deviations lay in an acceptable range for screening determinations.

\section{Correlation with comparison methods}

Serum determinations of barbiturates, benzodiazepines and tricyclic antidepressants were compared with results of the EMIT single test using the decision limit suggested by the manufacturer and a lowered decision limit. No negative results (fig. 1) were ob-

Tab. 4. Analytical precision of automated procedures for qualitative and quantitative methods in serum.

\begin{tabular}{|c|c|c|c|c|c|c|c|c|}
\hline \multirow[t]{2}{*}{ Analyte } & \multirow[t]{2}{*}{$\mathbf{N}$} & \multicolumn{3}{|c|}{ Within-run } & \multirow[t]{2}{*}{$\mathbf{N}$} & \multicolumn{3}{|c|}{ Between-run } \\
\hline & & Mean & SD & $\mathrm{CV}(\%)$ & & Mean & $\mathrm{SD}$ & CV $(\%)$ \\
\hline Barbiturates (mg/l) & $\begin{array}{l}10 \\
10\end{array}$ & $\begin{array}{l}0.80 \\
1.88\end{array}$ & $\begin{array}{l}0.04 \\
0.13\end{array}$ & $\begin{array}{r}11 \\
7\end{array}$ & $\begin{array}{r}19 \\
6\end{array}$ & $\begin{array}{l}1.09 \\
3.17\end{array}$ & $\begin{array}{l}0.38 \\
0.24\end{array}$ & $\begin{array}{c}35^{*} \\
8\end{array}$ \\
\hline Benzodiazepines (mg/l) & $\begin{array}{l}10 \\
10\end{array}$ & $\begin{array}{l}0.22 \\
0.27\end{array}$ & $\begin{array}{l}0.01 \\
0.02\end{array}$ & $\begin{array}{l}5 \\
8\end{array}$ & $\begin{array}{r}19 \\
6\end{array}$ & $\begin{array}{l}0.25 \\
0.30\end{array}$ & $\begin{array}{l}0.01 \\
0.05\end{array}$ & $\begin{array}{r}4 \\
17\end{array}$ \\
\hline Tricyclic antidepressants (mg/l) & $\begin{array}{l}10 \\
10\end{array}$ & $\begin{array}{l}0.23 \\
0.42\end{array}$ & $\begin{array}{l}0.009 \\
0.02\end{array}$ & $\begin{array}{l}4 \\
5\end{array}$ & $\begin{array}{r}19 \\
6\end{array}$ & $\begin{array}{l}0.23 \\
0.18\end{array}$ & $\begin{array}{l}0.02 \\
0.02\end{array}$ & $\begin{array}{r}9 \\
11\end{array}$ \\
\hline Acetaminophen $(\mathrm{mg} / \mathrm{l})$ & 10 & 46.5 & 6.1 & 13 & 8 & 128 & 7.4 & 6 \\
\hline Salicylates (mg/l) & $\begin{array}{l}10 \\
10\end{array}$ & $\begin{array}{r}73.4 \\
157.1\end{array}$ & $\begin{array}{l}2.67 \\
1.5\end{array}$ & $\begin{array}{l}4 \\
1\end{array}$ & $\begin{array}{r}19 \\
6\end{array}$ & $\begin{array}{c}71.8 \\
133\end{array}$ & $\begin{array}{l}3.24 \\
0.8\end{array}$ & $\begin{array}{l}5 \\
1\end{array}$ \\
\hline Ethạnol (g/l) & $\begin{array}{l}10 \\
10\end{array}$ & $\begin{array}{l}0.65 \\
2.75\end{array}$ & $\begin{array}{l}0.03 \\
0.034\end{array}$ & $\begin{array}{l}4.6 \\
1.2\end{array}$ & $\begin{array}{l}20 \\
10\end{array}$ & $\begin{array}{l}0.60 \\
2.03\end{array}$ & $\begin{array}{l}0.02 \\
0.045\end{array}$ & $\begin{array}{l}3 \\
2.2\end{array}$ \\
\hline
\end{tabular}

* concentration near detection limit

Tab. 5. Accuracy of automated procedures for qualitative and quantitative methods in serum.

\begin{tabular}{|c|c|c|c|c|c|}
\hline Analyte & Material & $\begin{array}{l}\text { Target value } \\
\mathrm{mg} / \mathrm{l}\end{array}$ & $\begin{array}{l}\text { Result } \\
\mathrm{mg} / \mathrm{l}\end{array}$ & $\begin{array}{l}\text { Difference } \\
\mathrm{mg} / \mathrm{l}\end{array}$ & $\begin{array}{l}\text { Deviation } \\
\%\end{array}$ \\
\hline Barbiturates & $\begin{array}{l}\text { Abbott L } \\
\text { EMIT st }\end{array}$ & $\begin{array}{l}3.0 \\
3.0\end{array}$ & $\begin{array}{l}2.9 \\
2.83\end{array}$ & $\begin{array}{l}0.1 \\
0.17\end{array}$ & $\begin{array}{l}-3 \\
-6\end{array}$ \\
\hline Benzodiażepines & $\begin{array}{l}\text { Abbott L } \\
\text { EMIT st }\end{array}$ & $\begin{array}{l}0.3 \\
0.3\end{array}$ & $\begin{array}{l}0.33 \\
0.32\end{array}$ & $\begin{array}{l}0.03 \\
0.02\end{array}$ & $\begin{array}{l}+10 \\
+7\end{array}$ \\
\hline Tricyclic antidepressants & $\begin{array}{l}\text { Abbott } M \\
\text { EMIT st }\end{array}$ & $\begin{array}{l}0.2 \\
0.2\end{array}$ & $\begin{array}{l}0.22 \\
0.16\end{array}$ & $\begin{array}{l}0.02 \\
0.04\end{array}$ & $\begin{array}{l}+10 \\
-20\end{array}$ \\
\hline Acetaminophen & $\begin{array}{l}\text { Syva Control } \\
\text { Biorad TDM } 3\end{array}$ & $\begin{array}{r}75 \\
135\end{array}$ & $\begin{array}{l}78.9 \\
126\end{array}$ & $\begin{array}{l}3.9 \\
9\end{array}$ & $\begin{array}{l}+5 \\
-7\end{array}$ \\
\hline Salicylates & $\begin{array}{l}\text { Biorad TDM } 2 \\
\text { Biorad TDM } 3\end{array}$ & $\begin{array}{l}156 \\
454\end{array}$ & $\begin{array}{l}159 \\
490\end{array}$ & $\begin{array}{r}3 \\
36\end{array}$ & $\begin{array}{l}+2 \\
+8\end{array}$ \\
\hline Ethanol & $\begin{array}{l}\text { Fluinorm } 1 \\
\text { Fluinorm } 2\end{array}$ & $\begin{array}{l}0.63 \\
1.52\end{array}$ & $\begin{array}{l}0.62 \\
1.55\end{array}$ & $\begin{array}{l}0.01 \\
0.03\end{array}$ & $\begin{array}{l}+1 \\
+2\end{array}$ \\
\hline
\end{tabular}


a) Barbiturates

EMIT st

proposed cut-off

EMIT st

lowered cut-off

b) Benzodiazepines

EMIT st

proposed cut-off

EMIT st

lowered cut-off

c) Tricyclic antidepressants

EMIT st

proposed cut-off

EMIT st

lowered cut-off

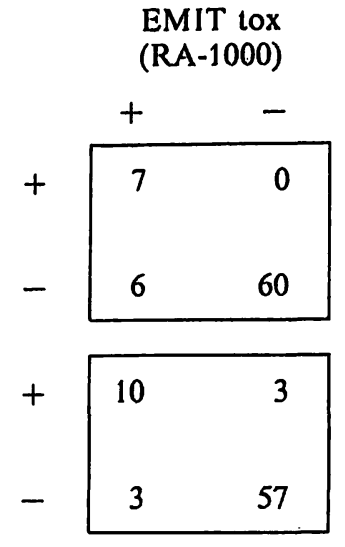

EMIT tox

(RA-1000)

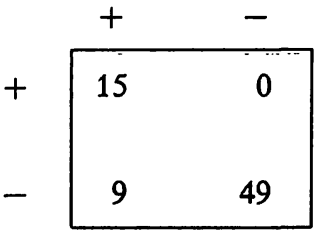

\begin{tabular}{rr}
20 & 2 \\
4 & 47 \\
\hline
\end{tabular}

EMIT tox

(RA-1000)

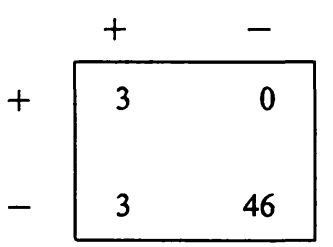

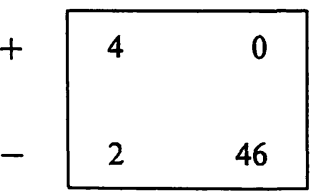

Fig. 1. Discrepancies between determinations using the RA1000 analyser and the EMIT st. For EMIT st two decision limits were used, that proposed by the manufacturer $(3.0 \mathrm{mg} / \mathrm{l}$ secobarbital; $0.3 \mathrm{mg} / \mathrm{l}$ diazepam; $0.2 \mathrm{mg} / \mathrm{l}$ nortriptyline) and the detection limit (sample blank).

served with the automated method on the RA- 1000 in comparison with the single test procedure. The greater number of positive results is probably due to the lower detection, e.g. decision limit of the automated procedure.

Fig. 2. Comparison of results from the present quantitative analytical procedures with those from other routinely used methods.

16-42 samples were analysed with the present quantitative procedures and with the comparison methods as indicated. Linear regression was calculated by the method of least squares (15) and by the method of Bablok et al. (16).

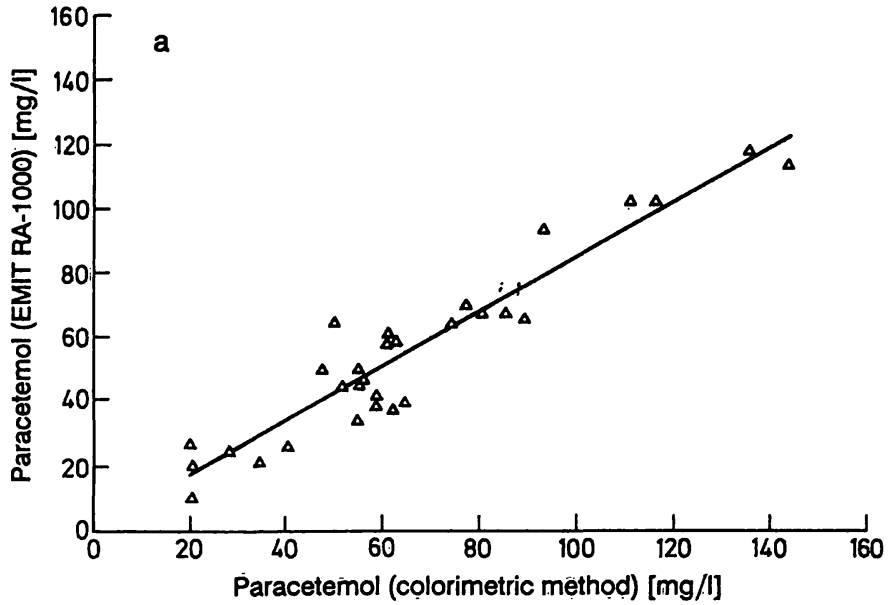

a. acetaminophen (paracetamol) compared with the method of Price (13).

linear regression: $\mathrm{n}=30 ; \mathrm{r}=0.946$

$$
y=-0.12+0.85 x
$$

Bablok et al.: $\quad y=-3.22+0.896 x$

10 more samples gave results $<10 \mathrm{mg} / 1$ with both methods.

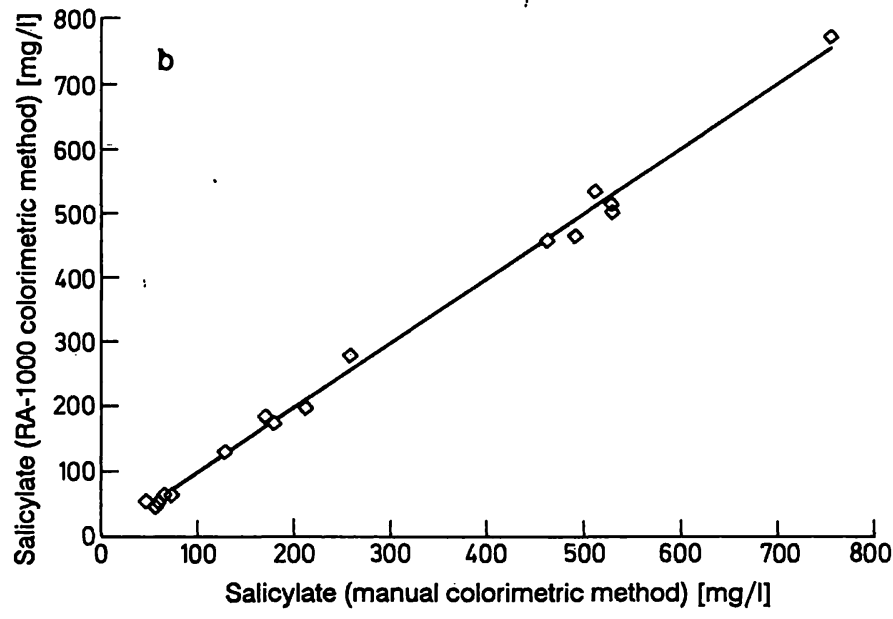

b. salicylate compared with the manual colorimetric method.

linear regression: $\mathbf{n}=16 ; \mathrm{r}=0.998$

$y=-1.5+0.998 x$

Bablok et al.: $\quad \mathrm{y}=-2.1+1 \mathrm{x}$

10 more samples gave results $<50 \mathrm{mg} / \mathrm{l}$ with both methods.

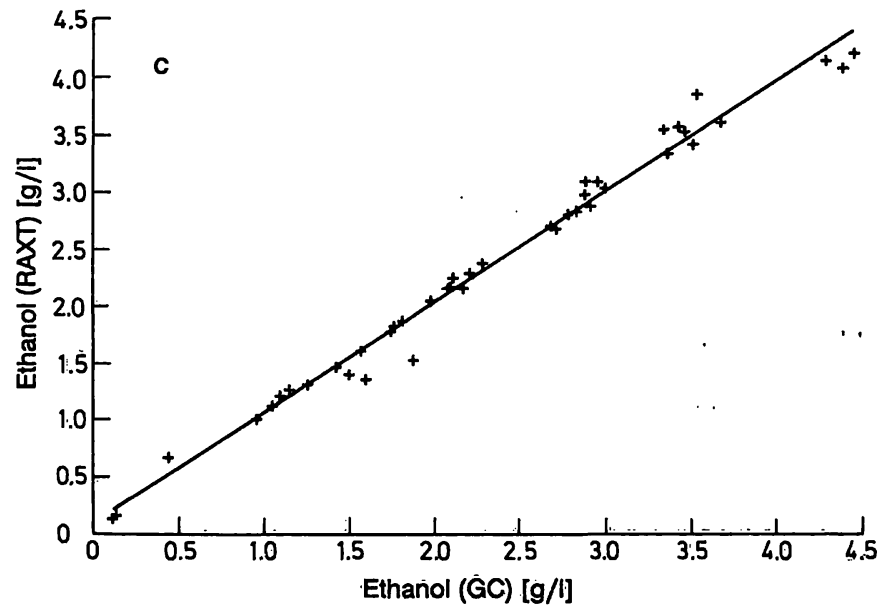

c. ethanol compared with headspace gas chromatography.

linear regression: $n=42 ; r=0.993$

$$
y=0.09+0.97 x
$$

Bablok et al.: $\quad y=0.06+0.98 x$

16 more samples gave results $<0.15 \mathrm{~g} / 1$ with both methods. 
The EMIT method for acetaminophen, which was adapted to the RA-1000 analyser, was compared with the manual colorimetric method of Price (13). The correlation coefficient was 0.946 (fig. 2a). From figure $2 a$ deviations up to $50 \%$ from the regression line for low concentrations can be seen. However, both methods fulfil the clinical requirements for detection and quantification of acetaminophen overdosage.

Figure $2 \mathrm{~b}$ compares the results for the analysis of salicylates in serum, using the present method and a manual procedure with the same test kit.

The ethanol determinations on the RA-1000/RAXT were compared with the candidate reference method (headspace gas chromatography). The results in figure $2 c$ exhibited a good correlation $(r=0.993)$. Only a very small intercept due to the more extended detection limit of gas chromatography was detected.

\section{Stability of working reagents and calibration curves}

Reconstituted reagents for EMIT methods and salicylates exhibited stability for at least 6 weeks at $4-8^{\circ} \mathrm{C}$. In routine use over three years, the stability of prediluted working reagents at $4-8^{\circ} \mathrm{C}$ was generally at least 14 days, as seen from a typical stability curve of controls measured daily without any recalibration (fig. 3).

The validity of calibration curves, when using working reagents from the same test kit, was checked by measuring accuracy controls. The maximal deviation allowed for keeping the old calibration curve was $30 \%$ for the qualitative procedures. It was usually unnecessary to perform a new calibration, when working solutions were prepared from the same reagent bottle.

Ethanol reagents were freshly prepared every two days, because of their limited stability.

The stability of serum samples using Vacutainer ${ }^{\circledR}$ tubes has been reported by others (20).

Analytical sensitivity and setting of the decision limits

The detection limits (sample blank) of the qualitative assays were found to be very low (tab. 3). The zero calibrator exhibited a higher absorption signal than nearly all the drug-free samples that were tested. This indicated a matrix difference between calibrators and freshly sampled serum or plasma, resulting in an obviously very low matrix dependence. To avoid possibly positive results from drug traces we decided to set the decision limits to the first calibrator concentration above zero.
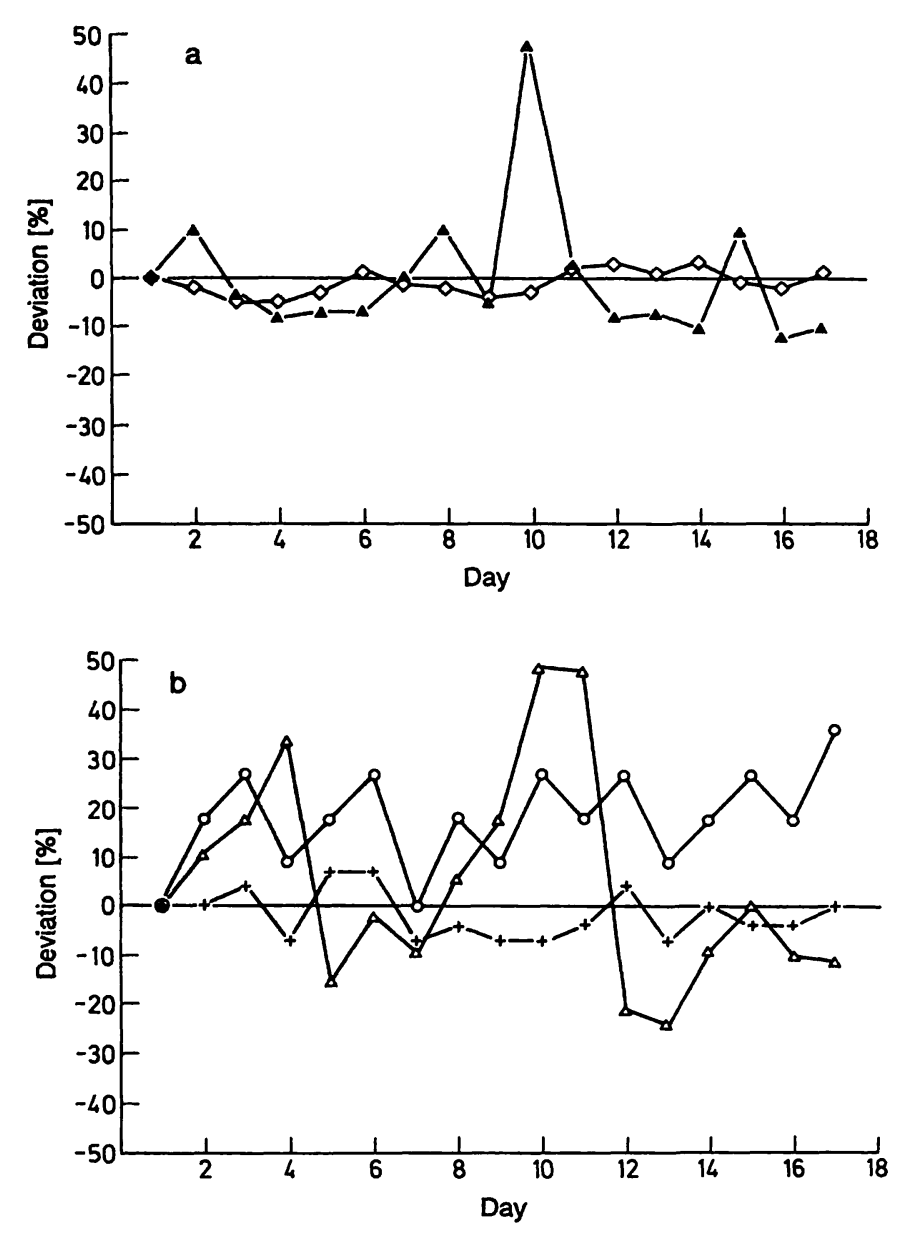

Fig. 3. Stability of reagents and calibration curves. Samples of a precision control material were analysed once a day over a period of 17 days without any recalibration. Values are given as deviation (\%) from the measurement at the first day.

Reagents were stored at $4-8^{\circ} \mathrm{C}$. First values were: 105 $\mathrm{mg} / \mathrm{l}$ salicylate $(\diamond) ; 1.60 \mathrm{mg} / \mathrm{l}$ barbiturates $(\Delta) ; 0.11$ $\mathrm{mg} / \mathrm{l}$ benzodiazepines (O); $7.3 \mathrm{mg} / \mathrm{l}$ paracetamol $(\Delta)$; $0.27 \mathrm{mg} / \mathrm{l}$ tricyclic antidepressants $(+)$.

a. quantitative assays

b. qualitative assays

These decision limits were:

barbiturates:

$0.5 \mathrm{mg} / 1$ (decision calibrator: secobarbital)

benzodiazepines: $0.05 \mathrm{mg} / 1$ (decision calibrator: nordiazepam)

tricyclic $\quad 0.07 \mathrm{mg} / \mathrm{l}$ (decision calibrator: antidepressants: nortriptyline)

Testing the analytical sensitivity for the determination of tricyclic antidepressants with the method introduced by Kutter (17), using a decision calibrator of $0.07 \mathrm{mg} / \mathrm{l}$ nortriptyline, resulted in $\mathrm{N}_{10}=0.05 \mathrm{mg} / \mathrm{l}$ and $\mathrm{N}_{90}=0.1 \mathrm{mg} / \mathrm{l}$ (fig. 4).

Lowering the decision limits produced a distinct increase of analytical sensitivity (tab. 6) compared with decision limits proposed by the manufacturer. 


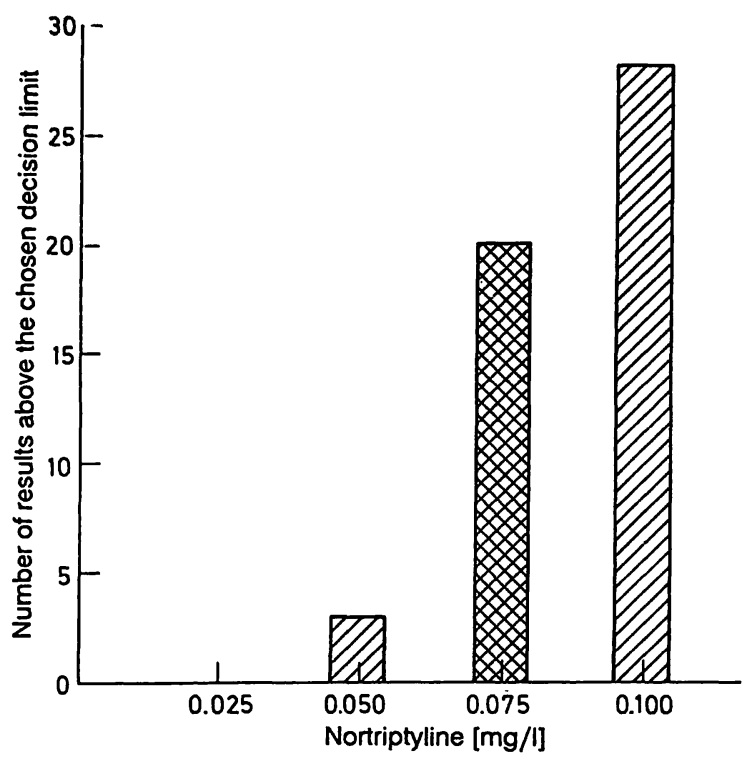

Fig. 4. Analytical sensitivity of the determination of tricyclic antidepressants.

According to Kutter (17), 30 different drug-free samples were spiked with increasing amount of nortriptyline and the concentrations measured were compared with the chosen decision limit $(0.07 \mathrm{mg} / \mathrm{l})$.

The decision values for the analgesics, paracetamol and salicylates, were set near to the upper therapeutic range limit (21):

acetaminophen: $10 \mathrm{mg} / \mathrm{l}$

salicylates: $\quad 50 \mathrm{mg} / \mathrm{l}$

Ethanol valúes less than $0.15 \mathrm{~g} / \mathrm{l}$ were not given quantitatively, in accordance with the recommendations of an expert group (22).

Use of the new analytical programme as a screening procedure

In order to demonstrate the diagnostic utility of the present programme, the results of its use over a 6 month period in our laboratory are summarized in table 7.

When analysed with the present analytical programme, 139 out of 188 serum samples $(74 \%)$ gave at least one positive result. As can be seen, benzodiazepines (40\%) and ethanol (36\%) were most frequently positive. The distribution of values observed is given in figure 5. Out of 188 samples, $28(15 \%)$ were positive for benzodiazepines in combination with ethanol. However, other combinations were detected as well.

Only in 70 of these 188 cases $(37 \%)$ were further determinations requested. Of these, $23(33 \%)$ showed no evidence of intoxication in a more extended screening procedure, using various urine tests (12). Of the remaining 47 patients 15 gave a positive result for
Tab. 6. Effect of lowered decision limits.

\begin{tabular}{lccc}
\hline & $\begin{array}{l}\text { Barbitu- } \\
\text { rates }\end{array}$ & $\begin{array}{l}\text { Benzodia- } \\
\text { zepines }\end{array}$ & $\begin{array}{l}\text { Tricyclic anti- } \\
\text { depressants }\end{array}$ \\
\hline $\begin{array}{l}\text { Proposed decision } \\
\text { limit (mg/l) }\end{array}$ & 3.0 & 0.3 & 0.2 \\
$\begin{array}{l}\text { Positive results } \\
\text { Negative results }\end{array}$ & 7 & 13 & 3 \\
$\begin{array}{l}\text { Lowered decision } \\
\text { limit (mg/l) }\end{array}$ & 69 & 63 & 52 \\
$\begin{array}{l}\text { Positive results } \\
\text { Negative results }\end{array}$ & 15 & 23 & 6.6 \\
\hline
\end{tabular}

Tab. 7. Application of the analytical programme to patients, where intoxication was suspected from anamnesis or clinical examination.

a) Total results (with use of the lowered decision limits)

$\begin{array}{lll}\mathrm{n}=188 & \text { Positive } & \text { Negative } \\ \text { Barbiturates } & 25 & 163 \\ \text { Benzodiazepines } & 81 & 107 \\ \text { Tricyclic antidepressants } & 27 & 161 \\ \text { Paracetamol } & 6 & 182 \\ \text { Salicylates } & 8 & 180 \\ \text { Ethanol } & 68 & 120\end{array}$

b) Combinations with positive benzodiazepines

$\mathrm{n}=81$

Barbiturates 15

Tricyclic antidepressants $\quad 13$

Paracetamol 3

Salicylates 5

Ethanol 28

c) Combinations with positive ethanol

$\mathrm{n}=68$

Barbiturates

Benzodiazepines

Tricyclic antidepressants $\quad 10$

Paracetamol 3

Salicylates 2

opiates in urine. A wide spectrum of other substances was detected with unspecific colour reactions, è. g. the tetrabromophenolphthaleinethylester reaction (23) and the Forrest reaction (3), therapeutic drug monitoring, thin layer chromatography and other immunoassays in ưrine. For clinical purposes, it was nècessary to send samples from only 5 patients to external laboratories for confirmation and identification of the drugs involved.

\section{Discussion}

General toxicological screening requires many analytical tools, e. g. colour tests (24), immunoassays (25), thin-layer chromatography $(26,27)$, gas chromatography $(28-30)$, high-performance liquid chromato- 

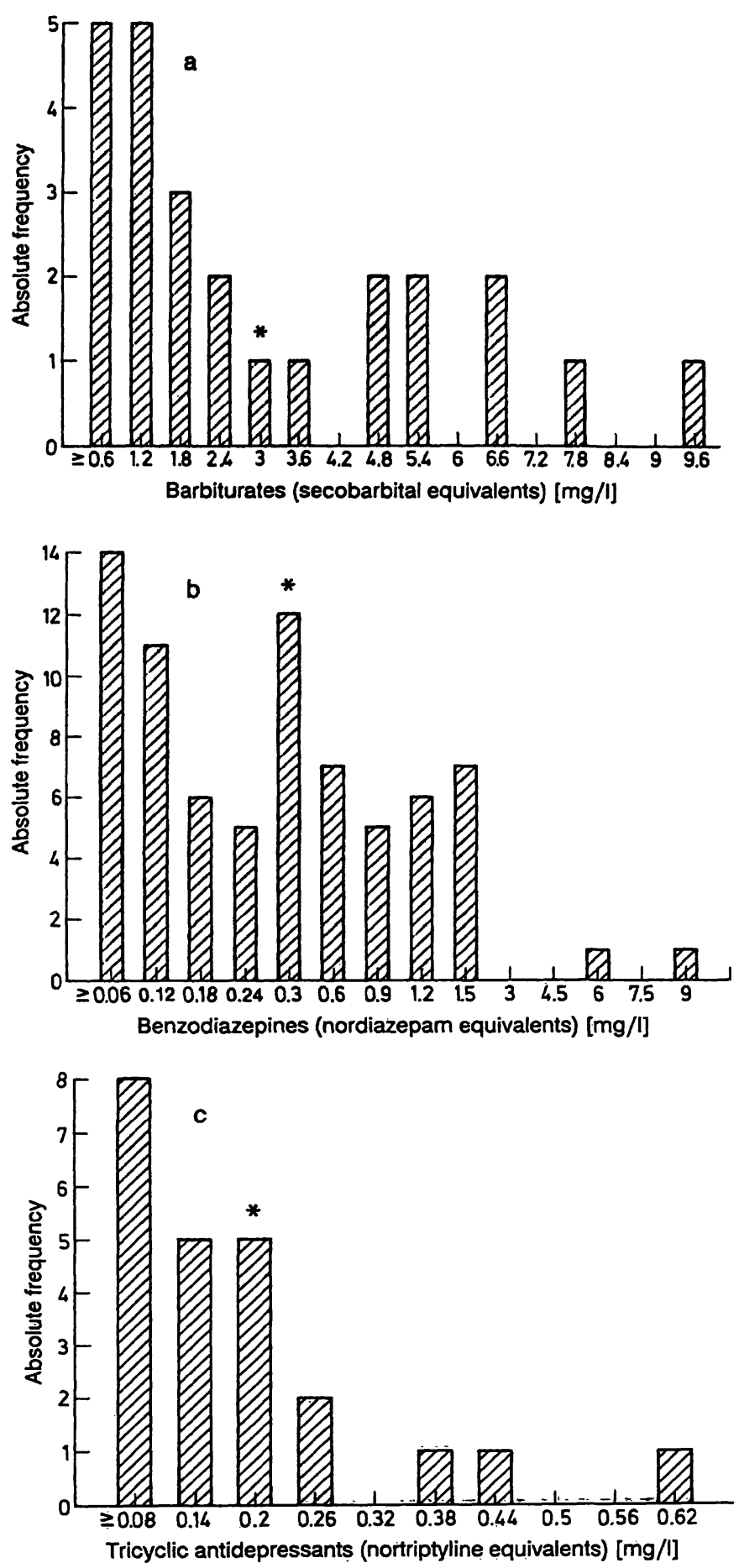

Fig. 5. Distribution of positive results measured in a total of 188 samples. The lowest concentration value given was used as the decision limit. The cut-off proposed by the manufacturer is marked by an asterisk.
a. barbiturate assay
b. benżodiazepine assay
c. tricyclic antidepressants assay

graphy $(31,32)$ and/or gas chromatography/massspectrometry $(33,34)$. In clinical toxicology, however, information obtained quickly with simple screening tests is very valuable $(35-37)$. On the other hand, haematological, haemostaseological and clinical chemistry parameters are additionally useful in acute poisoning $(36,38)$. This prompted us to adapt assays for frequent toxicologically relevant compounds to an mechanized analyser, which is routinely used for emergency clinical chemistry. The resulting advantages of this strategy are: no additional technical or personnel requirements, no time-consuming procedures (for example extraction), and high analytical precision and accuracy with a remarkable decrease of reagent costs.

\section{Decision limits}

A major aim of toxicological forefield analyses is to exclude intoxication. Cut-off values of qualitative screening tests should be lowered for this purpose as far as possible to avoid false negative findings, especially with substances exhibiting low cross-reactivity. As a consequence, however, these cut-off values are in the therapeutic range for several drugs. The qualitative EMIT tests presented here do not discriminate between acute intoxications and results due to therapeutic drug application. The applicability of the screening programme is, however, not restricted by this fact, if the main aim of forefield toxicological analysis is exclusion of intoxication with a high degree of certainty.

False positive findings, on the other hand, can be corrected by the results of more specific tests. Two cut-off limits (for example the lower decision limit and that proposed by the producer) may be used to separate "clinically precarious positive" from positive results. However, this procedure does not eliminate the problems resulting from differences in cross-reactivity. According to a common agreement (39), each positive result implying therapeutic or other consequences should be confirmed by a separate test procedure.

Very low detection limits were estimated from measurements of thirty different drug-free serum samples for the EMIT serum tests. The obviously very small matrix dependence of these procedures, however, was not observed when the tests were calibrated with aqueous standards (data not shown).

In view of matrix dependency, the accuracy of the test procedures should be demonstrated with various control materials. These are quantitative tests, although they are only qualitatively interpreted. A quality assurance programme as used for quantitative measurements was therefore installed.

The decision limits for the quantitative analgesic determinations (paracetamol and salicylates) were set to the upper therapeutic range, in accordance with the common use of these drugs and the relatively great imprecision of the quantitative methods in the lower concentration range. 
Application of the present programme as a screening procedure

The relative frequency of positive results with the different tests detected by our methodology was similar to the distribution of results found by Gibitz (36). These distributions are typical for non-specialized hospitals where intoxications of patients examined are usually not severe. Even in these cases, however, toxicological analysis is necessary for differential diagnostic purposes. Depending on the cut-off values used as the decision point for a positive result, the numbers of positives may vary by a factor of 2 . As can be deduced from the distribution of positive results as a function of present concentration ranges (fig. 5), the setting of cut-off values as proposed by the producer seems not to be optimal, since nearly equal numbers of samples exhibited values that were higher and lower than these cut-off values in all three group tests. The setting of the decision limit near the detection limit (sample blank) therefore seems to be more reliable. When the detection limit (sample blank) was used as the decision limit, the positive and negative results agreed well with those found in the single test procedures. Also, for example, low positive signals in the test for tricyclic antidepressants may be due to diphenhydramine cross-reativity, e. g. unspecific reactivity, but this is desirable for forefield toxicology. To increase the number of intoxications detectable by the present programme it seems advisable to add further tests like an immunoassay for opiates (in urine), the tetrabromophenolphthaleinethylester reaction for the detection of basic compounds (23) and the Forrest reactions for the detection of phenothiazines (3).

\section{References}

1. Geldmacher-v. Mallinckrodt, M. \& Guder, W. G. (1989) Umfrage der Senatskommission für klinisch-toxikologische Analytik der Deutschen Forschungsgemeinschaft und der Deutschen Gesellschaft für Klinische Chemie zur Situation der klinisch-toxikologischen Analytik an Krankenhäusern der Bundesrepublik Deutschland. Mitteilungen Dt. Ges. f. Klin. Chemie 20, 92-104.

2. DFG (Deutsche Forschungsgemeinschaft): Denkschrift (1983) Klinisch-toxikologische Analytik, Lage und Ausbaunotwendigkeit. Verlag Chemie, Weinheim, Germany.

3. M. Geldmacher-von Mallinckrodt (1976) Einfache Untersuchungen auf Gifte im klinisch-chemischen Laboratorium. Georg Thieme Verlag Stụttgart, Germany.

4. Jahrbuch' 90 zur Frage der Suchtgefahren (1989). Neuland Verlag, Hamburg.

5. Gibitz, H. J. (1987) Toxikologische Untersuchungen im Notfall-Labor. In: Das Notfall-Labor (Henkel, E., ed.) GIT Verlag, Darmstadt, Germany.

6. Schütz, H., Schneider, W. R. \& Schölermann, K. (1988) Verbessertes enzymimmunologisches Screeningverfabren für Benzodiazepine im Harn nach Extrelut ${ }^{R}$ Anreicherung. Ärztl. Lab. 34, 130-136.

\section{Future aspects and conclusions}

With respect to the necessity of automation in the modern emergency laboratory, we adapted toxicologically relevant test procedures for frequent drugs to the RA-1000/RAXT analyser. This programme might be extended in future by the inclusion of other immunoassays for more substances and/or groups, like diphenhydramin, antiarrhythmic and antihypertonic drugs. In our opinion the complete strategy for exclusion of intoxication will comprise the present fully automated programme, probably with some additions, and unspecific colour reactions. Positive results should then be further investigated and, if necessary, differentiated with more powerful tẹchnology such as gas chromatography/mass spectrometry.

In conclusion, the present serum screening programme proved to be a suitable first step in testing patients entering a non-specialized hospital, detecting $75 \%$ of total "positive" patients (11). The fully mechanized serum tests can be included in the programme of emergency laboratories, and they can be performed by the technician within 15 minutes with little addition to the workload. In addition the low reagent consumption keeps the reagent costs within an acceptable range.

\section{Acknowledgement}

We thank Prof. L. v.-Meyer (Department of forensic sciences, University of Munich) for the gas chromatography quantitation of ethanol.

7. Hausmann, E. (1990) Zum Nachweis von Benzodiazepinen aus Urin mit dem EMIT-st nach Festphasenextraktion. GIT Labor-Medizin, $320=324$.

8. Kanel-de, J., Dunlap, L. \& Hall, T. D. (1989) Extending the detection limit of the TDx fluorescence polarization immunoassay for benzoylecgonine in urine. Clin. Chem. 35, 2110-2112.

9. Meyer-V., L., Kauert, G. \& Drasch, G. (1988) Vergleich des Benzodiazepin-Screenings mittels FPIA (Abbott TDx) und DC im Bereich niedriger Konzentrationẹn. Beitr. Gerichtl. Med. 46, 143-147.

10. Hallbach, J., Hoffmann, G. \& Guder, W. G. (1987) Adaptation of analytical toxicology on the RA-1000 selective analyser. J. Clin. Chem. Clin. Biochem. 25, 610 (abstract).

11. Hallbach, J., Lindenmayer, S. \& Guder, W. G. (1989) Application of a toxicological screening programme to unselected hospitalized patients. J. Clin. Chem. Clin. Biochem. 27, $739-740$ (abstract).

12. Hallbach, J., Lindenmayer, S. \& Guder, W. G. (1990) Application of a toxicological screening programme to unselected hospitalized patients. Bulletin de la Societe des Sciences Medicales du Grand-Duche de Luxembourg (numero special) PO 2.02 (abstract). 
13. Price, C. P., Hammond, P. M. \& Scawen, M. D. (1983) Evaluation of an enzymic procedure for the measurement of acetaminophen. Clin. Chem. 29, 358-361.

14. Machata, G. (1964) Über die gaschromatographische Blutalkoholbestimmung, Analyse der Dampfphase. Mikrochim. Acta 6, 262-271.

15. Sachs, L. (1982) Statistische Methoden. Springer Verlag, Berlin, Heidelberg, New York.

16. Bablok, W., Passing, H., Bender, R. \& Schneider, B. (1988) A general regression procedure for method transformation. J. Clin. Chem. Clin. Biochem. 26, 783-790.

17. Kutter, D. (1983) Schnelltests in der klinischen Diagnostik. 2. Aufl., Urban \& Schwarzenberg, München, Wien, Baltimore.

18. Hubaux, A. \& Vos, G. (1970) Decision and detection limits for linear calibration curves. Anal. Chem. 42, 849-855.

19. Haeckel, R., Colic, D. \& Baud, M. Detectability, limits of detection and of quantitative determination in clinical chemistry. Eur. J. Clin. Chem. Clin. Biochem. submitted.

20. Bailey, D. N., Coffee, J. J. \& Briggs, J. R. (1988) Stability of drug concentrations in plasma stored in serum separator blood collection tubes. Therapeutic Drug Mon. 10, 352354.

21. DFG. Mitteilung XV der Senatskommission für Klinischtoxikologische Analytik (1990) Orientierende Angaben zu therapeutischen und toxischen Konzentrationen von Arzneimitteln und Giften im Blut, Serum oder Urin. VCH Verlagsgesellschaft, Weinheim, Germany.

22. DFG. Empfehlungen zur klinisch-toxikologischen Analytik: Durchfültrung und Interpretation der Bestimmung von Ethanol im klinisch-chemischen Laboratorium VCH Verlagsgesellschaft Weinheim, Germany. (in press).

23. Saker, E. G. \& Solomons, E. T. (1979) A rapid inexpensive presumptive test for phencyclidine and certain other crossreacting substances. J. Anal. Toxicol. 3, 220-221.

24. Stevens, H. M. (1986) Colour tests. In: Clarke's isolation and identification of drugs (Moffat, A. C., ed.) The Pharmaceutical Press, London, UK.

25. Stewart, M. J. (1986) Immunoassays. In: Clarke's isolation and identification of drugs (Moffat, A. C., ed.) The Pharmaceutical Press, London, UK.

26. DFG - Deutsche Forschungsgemeinschaft Mitteilung VII der Senatskommission für klinisch-toxikologische Analytik

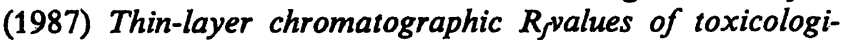
cally relevant substances on standardized systems. VCH Verlagsgesellschaft, Weinheim, Germany.

27. Simpson, D., Jarvie, D. R. \& Heyworth, R. (1989) An evaluation of six methods for the detection of drugs of abuse in urine. Ann. Clin. Biochem. 26, 172-181.
28. DFG - Deutsche Forschungsgemeinschaft Mitteilung II der Senatskommission für klinisch-toxikologische Analytik (1985) Gas-chromatographic retention indices of toxicologically relevant substances. VCH Verlagsgesellschaft, Weinheim, Germany.

29. Manca, D., Ferron, D. \& Weber, J. P. (1989) A system for toxicological screening by capillary gas chromatography with use of a drug retention index based on nitrogencontaining reference compounds. Clin. Chem. 35, 601607.

30. Külpmann, W. R. (1979) Eine einfache gaschromatographische Methode zur Bestimmung von Schlafmitteln im Serum. J. Clin. Chem. Clin. Biochem. 17, 115-121.

31. Daldrup, T., Michalke, P. \& Boehme, W. (1982) A screening test for pharmaceuticals, drugs and insecticides with reversed phase liquid chromatography - retention data of 560 compounds. Chromatogr. Newsletter 10,1-7.

32. Minder, E. I., Schaubhut, R. \& Vonderschmitt, D. J. (1988) Screening for drugs in clinical toxicology by high-performance liquid chromatography: identification of barbiturates by post-column ionization and detection by a multiplace photodiode array spectrophotometer. J. Chromatogr. 428, $369-376$.

33. Pfleger, K., Maurer, H. \& Weber, A. (1985) Mass spectral and GC-data of drugs, poisons and their metabolites. $\mathrm{VCH}$ Verlagsgesellschaft, Weinheim, Germany.

34. Maurer, H. (1989) Die moderne "general unknown"-Analyse mittels eines massenselektiven Detektors. In: DFG, Klinisch-toxikologische Analytik bei akuten Vergiftungen und Drogenmißbrauch (Gibitz, H.-J. \& Geldmacher-von Mallinckrodt, M., eds.) VCH Verlagsgesellschaft, Weinheim, Germany.

35. Gibitz, H.-J. (1984) Simple screening tests in clinical toxicology. In: Topics in forensic and analytical toxicology (Maes, R. A. A., ed.) Elsevier, Amsterdam, NL.

36. Gibitz, H.-J. (1988) Exogene Gifte (Klinisch-toxikologische Analytik). In: Labor und Diagnose - Indikation und Bewertung von Laborbefunden für die medizinische Diagnostik (Thomas, L., ed.) Die Medizinische Verlagsgesellschaft Marburg, Germany. pp. 1212-1234.

37. Carron Mc, M. M. (1983) The use of toxicology tests in emergency room diagnosis. J. Anal. Toxicol. 7, 132-135.

38. Prellwitz, W. (1983) Klinisch-chemische Analysen bei Vergiftungen. In: Soforttherapie bei Vergiftungen (Schuster, S. P., ed.) Perimed Fachbuch-Verlagsgesellschaft, Erlangen, Germany.

39. Schmid, I. \& Gibitz, H.-J. (1979) Bestätigungsanalysen bei klinisch-toxikologischen Untersuchungen. J. Clin. Chem. Clin. Biochem. 17, 186.

Dr. Jürgen Hallbach

Institut für Klinische Chemie

Städt. Krankenhaus München-Bogenhausen

W-8000 München 81

Bundesrepublik Deutschland 
